\title{
Język teorii naukowych wyjaśniających procesy społeczne. Wprowadzenie w problematykę
}

\begin{abstract}
Abstrakt
W artykule weryfikowano dwie hipotezy. Znaleziono argumenty na rzecz wycofania się z klasyfikacji języka danych wskazującej język behawioralny i fenomenologiczny, na rzecz wyodrębnienia języka nomotetycznego i idiograficznego jako kryterium naukoznawczej analizy teorii. Znaczenie tej drugiej klasyfikacji jest zgodne z praktyką analityczną, jaką stosował Madsen - twórca pojęć języka behawioralnego i fenomenologicznego. Bardziej skupiał się na kwestii obiektywizmu versus subiektywizmu i analizy uogólniającej versus indywidualizującej niż na tym, czego można było się spodziewać po oryginalnym znaczeniu pojęć języka fenomenologicznego i behawioralnego. Drugi wątek analityczny tego tekstu doprowadził do ustalenia, że ograniczenie języka danych do warstwy opisowej teorii - jak chciał Madsen - jest nieuprawnioną redukcją. A co za tym idzie wskazano potrzebę opracowania nowych klasyfikacji języka teorii dla jej wszystkich warstw.
\end{abstract}

Słowa kluczowe: język teorii naukowej, język fenomenologiczny, język behawioralny, naukoznawcza analiza teorii edukacji w naukach społecznych.

\section{The language of scientific theories explaining social processes. Introduction to issues}

\begin{abstract}
Two hypotheses were verified in the article. Arguments were found in favor of withdrawing from the classification of the data language indicating the behavioral and phenomenological language, approach for the separation of nomothetic and idiographic language as a criterion for the science-based analysis of theory. The meaning of this second classification is consistent with the analytical practice used by Madsen - the creator of the concepts of the behavioral and phenomenological language. He focused more on the issue of objectivism versus subjectivism and the generalizing analysis versus the individualizing one than on what could be expected
\end{abstract}

\footnotetext{
* Uniwersytet Mikołaja Kopernika w Toruniu, Wydział Nauk Pedagogicznych.
} 
from the original meaning of the concepts of the phenomenological and behavioral language. The second analytical thread of this text led to the conclusion that limiting the data language to the descriptive layer of the theory - as Madsen wanted - is an unauthorized reduction. Consequently, the need to develop new classifications of the language of theory referring to all its layers was highlighted.

Keywords: language of scientific theory, phenomenological language, behavioral language, science-related analysis of the theory of education in social sciences.

\section{Dwie hipotezy}

Ogólnym celem prezentowanego artykułu jest identyfikacja obszarów opisu języka teorii. Tekst ten nie wnika w głąb tych obszarów, ale zawiera próby ich zdefiniowania, przez co można go traktować jako „mapę” przydatną do szczegółowych badań nad językiem, a raczej językami teorii. Obniżając poziom ogólności formułowania celu tego tekstu, trzeba powiedzieć, że jest on też, a w zasadzie przede wszystkim, próbą zweryfikowania hipotezy Kristena Madsena (1980), który poziom języka teorii umieszcza w jej warstwie opisowej, a więc tej, która gromadzi, analizuje i interpretuje dane o badanych faktach, a także hipotezy o istnieniu dwóch języków opisu: fenomenologicznego i behawioralnego (Madsen 1980: 62-63).

Definiując podstawowe pojęcia tej analizy, przyjęto, że teoria jest tekstem naukowym, czyli zawierającym maksymalny ładunek usystematyzowanych informacji o badanych faktach, zorganizowanym na trzech poziomach abstrakcji: metateoretycznym, hipotetycznym i opisowym (Madsen 1980: 34-35). Poziom metateoretyczny buduje się, formułując lub przyjmując za innymi podstawowe twierdzenia filozoficzne, metodologiczne i metateoretyczne, wyznaczające paradygmatyczne ramy badania. Poziom hipotetyczny powstaje dzięki wyjaśnieniom, które są zasadniczym celem teorii naukowych. Na tym poziomie buduje się hipotezy, które na niższym poziomie ogólności podlegają weryfikacji. A ten kolejny poziom to poziom opisowy. Znajdują się tam zdania zawierające informacje o badanych faktach, odbywa się tam ich systematyzowanie, czyli analiza, oraz nadaje się tam znaczenia tym informacjom. Znaczenia te powstaną w ramach założeń przyjętych na poziomie metateoretycznym. Wyjaśniając kwestie języka, Madsen przypisuje go do warstwy opisowej i wyodrębnia dwa rodzaje języka teorii: fenomenologiczny i behawioralny (tamże: 62). Język fenomenologiczny był rozumiany jako nasycony terminami oznaczającymi zjawiska nieobserwowalne, opisującymi stany wewnętrzne badanych obiektów, terminami wieloznacznymi (np. osoba badana wyraziła troskę w związku z negatywnymi emocjami współmałżonka). Z kolei język behawioralny opisywał akty zachowania się, zjawiska obserwowalne na drodze empirycznej, stany zewnętrzne wobec badanych obiektów i operował terminami jednoznacznymi (np. osoba badana opuściła pomieszczenie w chwili, kiedy wszedł do niego współmałżonek). 


\section{Teoretyczna weryfikacja hipotez}

Z teoretycznego punktu widzenia wygodniej będzie zająć się najpierw hipotezą dotyczącą istnienia dwóch rodzajów języka. Używając terminu ,język fenomenologiczny", Madsen oparł się - najprawdopodobniej - na husserlowskim antyredukcjonizmie, który przesuwa znaczenie fenomenu poza bazę zmysłową, uwzględniając bazę symboliczną (Husserl 1975). Wskazują na to czynności analityczne zastosowane przez Madsena wobec danych z badań. Otóż zawsze etykietę „język fenomenologiczny" stosował tylko w odniesieniu do danych symbolicznych, np. aktów myślenia, wyobraźni. Ta redukcja jednak pomijała akty empiryczne, dane na drodze zmysłowej, co już było w sprzeczności z samą fenomenologią. Z tego punktu widzenia madsenowski ,język fenomenologiczny" nie jest językiem fenomenologicznym w rozumieniu fenomenologii, skoro pomija akty empiryczne. Podobnie rzecz ma się z rozumieniem świadomości. Madsen wyraźnie traktuje ją jako proces psychiczny powiązany z procesami fizycznymi, a więc traktuje ją naturalistycznie. Typowe jednak dla fenomenologii podejście antynaturalistyczne skupia się na czystym akcie świadomości, do którego można dojść drogą redukcji transcendentalnej, biorącej w nawias założenie o istnieniu świata naturalnego: fizycznego, psychicznego (w rozumieniu psychologii). „Język fenomenologiczny” w rozumieniu Madsena takiej redukcji nie dokonuje - jako wskaźniki języka fenomenologicznego występują dane odniesione do rzeczy, pojęć, teorii, zdarzeń (za dane fenomenologiczne Madsen (1980: 447) uznał dane zebrane przez A. Maslowa, na bazie których zbudował on teorię motywacji, nie fenomenologiczną przecież). W sumie można powiedzieć, że analizy wykonywane przez Madsena jako dane fenomenologiczne traktują dane oparte na różnych przedzałożeniach, odnoszone do teorii, podczas gdy w fenomenologii należy poruszać się bezałożeniowo i ateoretycznie. Jeśli zatem „język fenomenologiczny” nie miałby być tym językiem w znaczeniu fenomenologii, można zapytać, jaki jest jego desygnat. Poszukując odpowiedzi na to pytanie, sprawdzono, jakie dane, robiąc naukoznawcze analizy teorii motywacji, Madsen (1980) kategoryzował jako odpowiadające „językowi fenomenologicznemu”. Otóż były to dane $\mathrm{z}$ introspekcji, zbierane metodą wywiadów pogłębionych, dane z raportów psychoterapeutycznych, zapisków osobistych badanych ludzi oraz dane pochodzące $\mathrm{z}$ przeszukiwania źródeł wtórnych. Zawsze to były słowa, zdania pojedyncze bądź wielokrotnie złożone - zawierające zaimki osobowe, dotyczące zjawisk nieobserwowanych, do których docierano za pomocą wskaźników inferencyjnych odkrywanych w narracjach badanych lub w badanych tekstach. Ich wspólną cechą był fakt, że dotyczyły zjawisk nieobserwowalnych, wydobywanych ze świadomości lub podświadomości badanych, z tekstów pisanych drogą pośredniego wnioskowania. Na bazie takiego rozumowania można przyjąć, że „język fenomenologiczny" był rozumiany jako język opisu zjawisk nieobserwowalnych oraz zindywidualizowanych, zatem swoistych. Być może ten termin, zgodnie ze znaczeniem wydobytym z powyższej analizy, powinno się zamienić na termin „język 
idiograficzny" (od idios - swoisty), który byłby wolny od zawłaszczeń (np. fenomenologii), a jednocześnie bardziej pojemny, choć z wyraźną granicą.

Język behawioralny natomiast odnosił się do danych z różnego rodzaju pomiarów, ale nie tylko aktów zachowania. Za wskaźniki tego języka Madsen uznawał np. dane z badań sondażowych. Wskaźniki zmiennych były wówczas ukryte $\mathrm{w}$ twierdzeniach, pytaniach, do których ustosunkowywali się badani. Opisywali w ten sposób własne zachowanie, pokazywali, w jaki sposób myślą o zachowaniu, prognozowali, jak by się zachowali w określonej w twierdzeniu sytuacji, oraz dokonywali projekcji własnych stanów psychicznych (np. w testach osobowości). Warto jednak zauważyć, że ta projekcja nie była spontaniczna, nie była „swobodnym strumieniem świadomości", lecz reakcją sprowokowaną treścią twierdzenia lub pytania kwestionariusza. De facto była skanalizowaną reakcją osoby badanej, która na potrzeby pytania dokonywała „sprofilowanego” sortowania własnej świadomości. W tym sensie nie były to dane pochodzące ze spontanicznej narracji badanych (co odróżnia ten język od fenomenologicznego w rozumieniu Madsena), ale nie były to też - jak można sądzić - czyste dane behawioralne. Opis działania bowiem nie musi być tym samym co działanie, które można zarejestrować na drodze bezpośredniej obserwacji. Madsen pisał, że język behawioralny zawiera „zdania protokolarne", pozbawione kontekstu, opisy czystych aktów zachowania. W tym sensie desygnat pojęcia „język behawioralny” jest węższy niż to, co przy jego pomocy opisywał Madsen. W tej sytuacji pojawiają się dwa wyjścia. Jedno to pozostawienie terminu „język behawioralny" do opisu czystych aktów zachowania się, a znalezienie terminu trafnie oddającego zawartość powstałej nadwyżki znaczeniowej tego języka. To trudne zadanie, wykraczające poza cele tego artykułu. A drugie to znalezienie pojęcia trafnie obejmującego wszystkie rodzaje danych, które nie są idiograficzne czy fenomenologiczne $\mathrm{w}$ madsenowskim znaczeniu. Zabieg taki musi jednak uwzględnić kryterium klasyfikacyjne, na mocy którego oba rodzaje języka pokryją przestrzeń tekstu naukowego. Trzymając się drugiej opcji, warto zapytać, co jest cechą wspólną danych, które przypisuje się do języka behawioralnego. Działania analityczne Madsena pokazują, że jest to obserwowalność badanych zjawisk. Obserwowalność w takim sensie, że badane obiekty poprzez swoją aktywność w trakcie zbierania danych zostawiają wskaźniki możliwe do przyporządkowania do wcześniej zdefiniowanych kategorii, inaczej wariantów zmiennych. Widać tutaj dwa warunki, które uwzględniał Madsen. Pierwszy, efekty działania badanych są dostępne na drodze zmysłowej i powiązany z nim drugi, wszyscy badani wpisują swoją aktywność w przygotowane wcześniej warianty. A to oznacza, że tak rozumiane dane mogą być zmieniane na liczby obrazujące tendencje populacyjne w poszczególnych kategoriach, jednakowych dla wszystkich. Wydaje się więc, że mowa tutaj o języku opisu ogólnych prawidłowości, dającym powierzchowny, ale szeroki ogląd badanych zjawisk. Nie jest to więc język behawioralny (dane nim opisywane wykraczają poza akty zachowania), a raczej język nomotetyczny, opisujący populacyjne prawidłowości. Świadczy o tym też fakt, że wspólną cechą danych 
opisywanych przez Madsena jako behawioralne jest ich wyrażanie w postaci liczb oraz, że w każdym przypadku hipotezy weryfikowane na ich podstawie odnoszą się do populacji generalnej.

Tak więc wobec faktu, że pojęcia języka fenomenologicznego i behawioralnego posiadają - na mocy wykonanej analizy - inne desygnaty niż te, których można by się spodziewać, kierując się wiedzą o fenomenologii i behawioryzmie, można hipotetycznie wprowadzić w ich miejsce język idiograficzny i nomotetyczny. Jednak, choć obie kategorie pojęciowe zawierają w sobie wcześniejsze desygnaty języka fenomenologicznego i behawioralnego, taka klasyfikacja jest nadal redukcyjna w stosunku do tego, co można myśleć o języku teorii w ogóle. Ten problem istniał też u Madsena. Przy czym redukcja dokonana przez niego ograniczała język teorii jedynie do warstwy opisowej. Użycie proponowanej klasyfikacji pozwala już nim się posługiwać niemal we wszystkich warstwach teorii, co za chwilę podczas weryfikacji drugiej hipotezy zostanie pokazane. Niemniej jednak ta klasyfikacja również jest zbyt redukcjonistyczna, bo oparta tylko na jednym z możliwych kryteriów naukoznawczego oglądu języka danych. Poza tym jest bardziej efektem krytycznego spojrzenia na pomysł Madsena, powstałego po praktycznym zastosowaniu tego kryterium w analizie teorii (Rubacha 2017: 19), niż systematyczną próbą uporania się z językiem danych.

Druga $\mathrm{z}$ hipotez poddawanych weryfikacji $\mathrm{w}$ tym artykule umieszcza język danych tylko $\mathrm{w}$ warstwie opisowej teorii. Ten problem łączy się z weryfikacją pierwszej hipotezy. Nie można się dziwić Madsenowi, że dokonał takiego zabiegu, skoro posługiwał się pojęciami języka fenomenologicznego i behawioralnego. Są one ograniczone $\mathrm{w}$ tym sensie, że odnoszą się jedynie do bazy danych empirycznych, stanowiących podstawę do rozstrzygnięć w warstwie hipotetycznej. Nie mogą być użyte do opisu języka bardziej abstrakcyjnych warstw teorii niż opisowa. Kiedy jednak myślimy o języku danych, trudno zgodzić się z redukcją sugerującą, że dane teorii to tylko jej baza empiryczna. Ponadto, jeśli teoria jest tekstem, jak chce tego Madsen (1980: 34), język jest jego głównym składnikiem formalnym. Potrzebne jest więc narzędzie do opisu języka (języków) wszystkich warstw teorii. Zwłaszcza jeśli jest on, a jest, zróżnicowany znaczeniowo. Wskazują już na to dane z warstwy metateoretycznej. Przyjęcie którejkolwiek wersji rozwiązania problemu ontologicznego teorii uruchamia określony język nadawania znaczeń. Neutralny monizm, najczęściej stosowana ontologia w naukach społecznych i w pewnej części nauk przyrodniczych (np. w psychiatrii, w naukach o zdrowiu, w antropologii fizycznej), nie generuje języków odpowiadających materializmowi i idealizmowi, lecz trzeci język dający się wyprowadzić z prac K. Darwina. Fakt oglądania przedmiotu badań z dwóch perspektyw nie oznacza bowiem ich dwóch niezależnych oglądów. Ta trzecia ontologia (neutralny monizm) jest dowodem na to, że rzeczy istnieją o tyle, o ile mogą być przedstawione w języku i są tym, czym język ich opisu. Podobnie można myśleć o twierdzeniach epistemologicznych, uruchamiających w warstwie hipotetycznej teorii dominującą strategię poznania naukowego. Empiryzm logiczny 
jest wyrażany w języku behawiorystycznym, ale empiryzm konwencjonalny wykracza poza jego zasięg, ponieważ odwołuje się do różnych teorii nadających znaczenia tzw. czystym faktom. Podobnie jest z racjonalizmem i intuicjonizmem, które możliwe są do wyrażenia w kilku językach, m.in. logiki formalnej i procesów emocjonalnych. Z takim zróżnicowaniem nie mógł sobie poradzić układ dwóch języków danych: fenomenologicznego i behawioralnego. Podobnie jest na niższym poziomie abstrakcji, gdzie pojawiają się zróżnicowane języki wyjaśnień: dedukcyjnych, statystycznych, teleologicznych, modelowych, indeterministycznych, aksjologicznych, nie mówiąc o językach metod badań czy terminów wyjaśniających. Te ostatnie mogą odwoływać się do różnych dyscyplin naukowych, a w ich obrębie do różnych teorii. Ich dodatkowe znaczenie, na przykład w naukach o wychowaniu i zdrowiu, często odwołuje się do psychologii, która oferuje mentalistyczne, fizjologiczne i neutralne znaczenia dodatkowe. Przyjęcie któregoś z nich oznacza uruchomienie konkretnego języka danych.

Powyższe argumenty nie pozwalają w naukoznawczej analizie teorii ograniczyć kwestii języka danych do warstwy opisowej. Przy czym nie można też sądzić, że istnieje uniwersalna klasyfikacja języka teorii, która jest możliwa do zastosowania we wszystkich ich warstwach oraz, że będzie ona wyczerpująca. Być może propozycja języka idiograficznego i nomotetycznego jest w stanie pokryć większość elementów trzech warstw teorii. Wydaje się, że radzi sobie z warstwą metateoretyczną i opisową w całości. W sensie znaczeniowym odpowiada strategiom badań (idiograficzna i nomotetyczna), które w warstwie metateoretycznej stanowią najważniejszy element decydujący o paradygmatycznych ramach badania i teorii, zarówno w odniesieniu do twierdzeń ontologicznych, jak i epistemologicznych. Podobnie jest z warstwą opisową, ponieważ zebrane dane empiryczne są bazą dla analiz weryfikujących hipotezy lub pytania badawcze. Analiza statystyczna danych empirycznych uruchamia język nomotetyczny, zaś analiza tekstu uruchamia język idiograficzny. Nieco inaczej może być z warstwą hipotetyczną. Nie ma pewności bowiem, czy posługiwanie się którymś z tych języków pozwoli skutecznie analizować wszystkie rodzaje wyjaśnień. Niektóre z nich, jak na przykład wyjaśnienia aksjologiczne, wykraczają znacznie poza kontekst swoistości - ogólności, choć inne, jak wyjaśnienia dedukcyjne czy statystyczne, precyzyjnie wpisują się w język nomotetyczny. Podobne wątpliwości można formułować pod adresem terminów wyjaśniających, które są bardzo skontesktualizowane teoretycznie, a problem swoistości - ogólności wydaje się być tu wtórnym. Kwestia warstwy hipotetycznej jest bardzo złożona i wymaga oddzielnego opracowania z punktu widzenia jej języka.

Wracając do wątku z poprzedniego akapitu, trzeba powiedzieć, że nawet jeśli klasyfikacja języka wskazująca język idiograficzny i nomotetyczny, zamiast fenomenologicznego i behawioralnego, pokrywa większość danych teorii naukowej, to jest oparta na jednym z wielu kryteriów ważnych z punktu widzenia naukoznawczej analizy. W tym sensie nie wnosi nic nowego ponad to, co ustalił Madsen. 
Akcentuje jedynie kryterium zasięgu i głębokości wglądu, jaki może mieć teoria w swój przedmiot badania. Nie odnosi się natomiast to takich kwestii, jak choćby język terminów wyjaśniających, ich znaczeń dodatkowych, język metod zbierania danych, język ich analiz, interpretacji itd. A potem wyjaśnienia wymagają kryteria ich łączenia w obrębie teorii i zachowania zasady niesprzeczności paradygmatycznej.

Podsumowując i wracając do celu tego artykułu, można przyjąć, że - w świetle przeprowadzonego rozumowania - język fenomenologiczny i behawioralny nie jest adekwatnym narzędziem analizy warstwy opisowej teorii, że użycie tej klasyfikacji jako narzędzia analizy teorii pokazuje inne jej aspekty niż oczekiwane na podstawie rozumienia tych terminów. Drugi wniosek odnosi się do teorii jako całości i skłania do poszukiwania kryteriów rozpoznawania języków teorii, ponieważ ograniczenie tej kwestii do warstwy opisowej wydaje się nieuprawnionym redukcjonizmem.

\section{Bibliografia}

Husserl E. (1975) Idee czystej fenomenologii i fenomenologicznej filozofii, t. 1, tłum. D. Gierulak, Warszawa, PWN.

Madsen K. (1980) Współczesne teorie motywacji, Warszawa, PWN.

Rubacha K. (2017) Naukoznawcza analiza prac teoretycznych, badawczych i metodycznych Profesor Marioli Chomczyńskiej-Rubachy, „Przegląd Badań Edukacyjnych”, nr 25/2, s. 11-39. 